\title{
ACPD
}

14, 10135-10166, 2014

\section{The influence of nitrogen oxides on the activation of bromide and chloride in salt aerosol}

S. Bleicher ${ }^{1}$, J. C. Buxmann ${ }^{2,{ }^{*}}$, R. Sander ${ }^{3}$, T. P. Riedel ${ }^{4}$, J. A. Thornton ${ }^{4}$, U. Platt ${ }^{2}$, and C. Zetzsch ${ }^{1}$

${ }^{1}$ Atmospheric Chemistry Research Unit, University of Bayreuth, Bayreuth, Germany

${ }^{2}$ Institut für Umweltphysik, University of Heidelberg, Heidelberg, Germany

${ }^{3}$ Air Chemistry Department, Max-Planck Institute for Chemistry, Mainz, Germany

${ }^{4}$ University of Washington, Seattle, USA

"now at: Met Office, Exeter, UK

Received: 6 March 2014 - Accepted: 11 March 2014 - Published: 22 April 2014

Correspondence to: C. Zetzsch (cornelius.zetzsch@uni-bayreuth.de)

Published by Copernicus Publications on behalf of the European Geosciences Union.

Influence of $\mathrm{NO}_{\mathrm{x}}$ on the activation of $\mathrm{BrO}$ and $\mathrm{CIO}$ in salt aerosol

S. Bleicher et al.

\section{Title Page}

Abstract

Conclusions

Tables

14

Back
Introduction

References

Figures

$\Delta$

Close

\section{Full Screen / Esc}

Printer-friendly Version

Interactive Discussion 


\section{Abstract}

Experiments on salt aerosol with different salt contents were performed in a Teflon chamber under tropospheric light conditions with various initial contents of nitrogen oxides $\left(\mathrm{NO}_{\mathrm{x}}=\mathrm{NO}+\mathrm{NO}_{2}\right)$. A strong activation of halogens was found at high $\mathrm{NO}_{\mathrm{x}}$ 5 mixing ratios, even in samples with lower bromide contents such as road salts. The ozone depletion by reactive halogen species released from the aerosol, was found to be a function of the initial $\mathrm{NO}_{\mathrm{x}}$ mixing ratio. Besides bromine, large amounts of chlorine have been released in our smog chamber. Time profiles of the halogen species $\mathrm{Cl}_{2}, \mathrm{Br}_{2}, \mathrm{ClNO}_{2}, \mathrm{BrNO}_{2}$ and $\mathrm{BrO}, \mathrm{ClO}, \mathrm{OClO}$ and $\mathrm{Cl}$ atoms were simultaneously measured by various techniques (chemical ionization mass spectrometry, differential optical absorption spectrometry coupled with a multi-reflection cell and gas chromatography of hydrocarbon tracers for $\mathrm{Cl}$ and $\mathrm{OH}$, employing cryogenic preconcentration and flame ionization detection). Measurements are compared to calculations by the CAABA/MECCA 0-D box model, which was adapted to the chamber conditions and took the aerosol liquid water content and composition into account. The model results agree reasonably with the observations and provide important information about the prerequisites for halogen release, such as the time profiles of the aerosol bromide and chloride contents as well as the aerosol $\mathrm{pH}$.

\section{Introduction}

Due to their high reactivity, bromine and chlorine have a strong impact on the chemistry of the atmosphere. In contrast to the situation in the stratosphere, their presence in the troposphere seems to be dominated by natural sources such as sea spray. Especially chlorinated species are difficult to measure directly, resulting in a challenge to infer a budget of total reactive chlorine in the lower atmosphere. Recent studies suggest that

25 a significant fraction of the tropospheric $\mathrm{Cl}^{\bullet}$ source is anthropogenic (Thornton et al., 2010). Although the mechanisms of halide activation, namely the conversion of inactive
ACPD

14, 10135-10166, 2014

Influence of $\mathrm{NO}_{\mathrm{x}}$ on

the activation of $\mathrm{BrO}$

and $\mathrm{ClO}$ in salt

aerosol

S. Bleicher et al.

Title Page

Abstract

Introduction

Conclusions

References

Tables

Figures

14

$>1$

4

Back

$>$

Close

Full Screen / Esc

Printer-friendly Version

Interactive Discussion 
halides into reactive halogen species (e.g. halogen oxides), are not fully understood, it is known that the $\mathrm{pH}$-value (Betts and Mackenzie, 1951; Fickert et al., 1999; da Rosa and Zetzsch, 2001) and the bromide to chloride ratio (Behnke et al., 1999) have an impact on the activation cycles. Especially the role of $\mathrm{NO}_{\mathrm{x}}$ molecules is under discus5 sion. Recently, Lopez-Hilfiker et al. (2012) and Wren et al. (2013) found the production of gaseous chlorine and bromine molecules from $\mathrm{NaCl} / \mathrm{NaBr}$-doped and acidified ice surfaces, which was also observed in nature (Pratt et al., 2013) The acidification of such ice surfaces and aerosol droplets can be caused by nitrogen oxides, in particular by the production of $\mathrm{N}_{2} \mathrm{O}_{5}$ during nighttime and its hydrolysis and dissociation to $\mathrm{H}^{+}$ and $\mathrm{NO}_{3}^{-}$on aqueous surfaces (George et al., 1994; Schütze et al., 2002):

$\mathrm{NO}_{3}+\mathrm{NO}_{2} \rightarrow \mathrm{N}_{2} \mathrm{O}_{5}$

$\mathrm{N}_{2} \mathrm{O}_{5}+\mathrm{H}_{2} \mathrm{O} \rightarrow 2 \mathrm{HNO}_{3}$

Nitric acid can also be formed during daytime by the reaction of $\mathrm{NO}_{2}$ with $\mathrm{OH}$ (e.g. Hippler et al., 2006):

$\mathrm{NO}_{2}+\mathrm{OH}+\mathrm{M} \rightarrow \mathrm{HNO}_{3}+\mathrm{M}$

However, the first halogen molecules (indicated by $\mathrm{X}$ or $\mathrm{Y}=\mathrm{Cl}, \mathrm{Br}$ ) can be activated by dissolved ozone (aqueous species are indicated by "aq") even during nighttime (e.g. Hunt et al., 2004):

$\mathrm{O}_{3} \rightarrow \mathrm{O}_{3}(\mathrm{aq})$

$\mathrm{O}_{3}(\mathrm{aq})+\mathrm{X}^{-} \rightleftharpoons \mathrm{XO}^{-}+\mathrm{O}_{2}$

$\mathrm{XO}^{-}+\mathrm{H}^{+} \rightleftharpoons \mathrm{HOX}(\mathrm{aq})$

$\mathrm{HOX}(\mathrm{aq})+\mathrm{H}^{+}+\mathrm{X}^{-} \rightarrow \mathrm{X}_{2}(\mathrm{aq})+\mathrm{H}_{2} \mathrm{O}$

$\mathrm{HOX}(\mathrm{aq})+\mathrm{H}^{+}+\mathrm{Y}^{-} \rightarrow \mathrm{XY}(\mathrm{aq})+\mathrm{H}_{2} \mathrm{O}$

ACPD

14, 10135-10166, 2014

Influence of $\mathrm{NO}_{\mathrm{x}}$ on

the activation of $\mathrm{BrO}$

and $\mathrm{ClO}$ in salt

aerosol

S. Bleicher et al.

Title Page

Abstract

Introduction

Conclusions

References

Tables

Figures

14

I

4

Back

Close

Full Screen / Esc

Printer-friendly Version

Interactive Discussion 
$\mathrm{X}_{2}(\mathrm{aq}) \rightarrow \mathrm{X}_{2}$

During the daytime the gaseous halogen molecules are photolyzed to two halogen atoms, which rapidly react with ozone:

$\mathrm{X}_{2}+h v \rightarrow 2 \mathrm{X}$

${ }_{5} \mathrm{X}+\mathrm{O}_{3} \rightarrow \mathrm{XO}+\mathrm{O}_{2}$

The formed bromine oxide is known to effectively deplete ozone catalytically due to its self-reaction:

$2 \mathrm{BrO} \rightarrow 2 \mathrm{Br}+\mathrm{O}_{2}$

$\rightarrow \mathrm{Br}_{2}+\mathrm{O}_{2}$

10 The branching ratio of Reactions (R11a)/(R11)(overall) is reported to be $\sim 0.85$ and formation of $\mathrm{OBrO}$ and $\mathrm{Br}$ is considered to be unimportant (Atkinson et al., 2007). However, under the influence of light $\mathrm{Br}_{2}$ is photolyzed rapidly (photolysis rates can be found in the Supplement). In the mixed case of additional activated chlorine, the depletion of ozone is even faster. Then $\mathrm{BrO}$ may also react with $\mathrm{ClO}$ to form a $\mathrm{Br}$ atom

15 and an intermediate $\mathrm{OCIO}$ molecule. $\mathrm{OCIO}$ in turn reacts with chlorine atoms back to $\mathrm{ClO}$ :

$\mathrm{BrO}+\mathrm{ClO} \rightarrow \mathrm{OClO}+\mathrm{Br}$

$\rightarrow \mathrm{ClOO}+\mathrm{Br}$

20

$\rightarrow \mathrm{BrCl}+\mathrm{O}_{2}$

$\mathrm{OClO}+\mathrm{Cl} \rightarrow 2 \mathrm{ClO}$

Influence of $\mathrm{NO}_{\mathrm{x}}$ on

the activation of $\mathrm{BrO}$

and $\mathrm{CIO}$ in salt

aerosol

S. Bleicher et al.

Title Page

Abstract

Introduction

Conclusions

References

Tables

Figures

14

4

Back

>

Close

Full Screen / Esc

$\mathrm{XO}$ radicals may also react with hydroperoxyl radicals to form hypohalide acids, which are the driver of Reaction (R7) after their uptake into the aqueous phase:

$\mathrm{XO}+\mathrm{HO}_{2} \rightarrow \mathrm{HOX}+\mathrm{O}_{2}$

$25 \mathrm{HOX} \rightarrow \mathrm{HOX}(\mathrm{aq})$ 
The aquatic uptake of one molecule containing one halogen atom and the subsequent release of one molecule containing two halogen atoms into the gas phase results in a self-accelerating autocatalytic activation of halides and thus is called "halogen explosion" (Platt and Janssen, 1995; Hönninger et al., 2004). Under remote conditions 5 the halogen explosion occurs rather for $\mathrm{X}=\mathrm{Br}$ than for $\mathrm{X}=\mathrm{Cl}$. One reason is the faster uptake of $\mathrm{HOBr}$ compared to $\mathrm{HOCl}$, due to the higher $\mathrm{p} K_{\mathrm{a}}$ value of $\mathrm{HOBr}\left(\mathrm{p} K_{\mathrm{a}}=7.8\right.$ at $273 \mathrm{~K}$ for $\mathrm{HOCl}$, (Morris, 1966), and a $\mathrm{p} K_{\mathrm{a}}=8.6$ at $274 \mathrm{~K}$ for $\mathrm{HOBr}$, Shilov, 1938). Additionally the release of $\mathrm{X}, \mathrm{Y}=\mathrm{Br}$ is favored over $\mathrm{X}=\mathrm{Cl}$ and $\mathrm{Y}=\mathrm{Br}$ or $\mathrm{X}, \mathrm{Y}=\mathrm{Cl}$ due to water phase reaction constants (Fickert et al., 1999). In polluted areas the activation 10 can be accelerated by $\mathrm{XNO}_{3}$, which accrues in the reaction of $\mathrm{XO}$ and $\mathrm{NO}_{2}(\mathrm{Cox}$ and Lewis, 1979; Sander et al., 1981):

$\mathrm{XO}+\mathrm{NO}_{2}+\mathrm{M} \rightarrow \mathrm{XNO}_{3}+\mathrm{M}$

$\mathrm{XNO}_{3} \rightarrow \mathrm{XNO}_{3}(\mathrm{aq})$

$\mathrm{XNO}_{3}(\mathrm{aq})+\mathrm{H}_{2} \mathrm{O} \rightarrow \mathrm{HOX}(\mathrm{aq})+\mathrm{H}^{+}+\mathrm{NO}_{3}^{-}$

$\mathrm{XNO}_{3}$ have a faster uptake to the aqueous phase than HOX (e.g. Hanson et al., 1996; Deiber et al., 2004) and its hydrolysis also provides protons needed by Reaction (R7).

Additionally, heterogeneous reactions are known to influence the halogen chemistry (summarized by Rossi, 2003). E.g. the uptake of $\mathrm{N}_{2} \mathrm{O}_{5}$ on halide aqueous phase leads to a direct transition of the halides to gaseous photolabile reservoir species (e.g. 20 George et al., 1994):

$\mathrm{N}_{2} \mathrm{O}_{5}+\mathrm{X}^{-}(\mathrm{aq}) \rightarrow \mathrm{XNO}_{2}+\mathrm{NO}_{3}^{-}(\mathrm{aq})$

This heterogeneous activation mechanism was originally proposed and investigated by Finlayson-Pitts et al. (1989) and confirmed in an aerosol smog chamber by Zetzsch and Behnke (1992) and Behnke et al. $(1993,1997)$ for chlorine and investigated in detail in a wetted-wall flow-tube by Frenzel et al. (1998), including $\mathrm{X}=\mathrm{Br}$. The production of CINO2 has been observed by Osthoff et al. (2008) in the polluted subtropical marine boundary layer. It alters. The production of $\mathrm{CINO}_{2}$ alters the $\mathrm{NO}_{\mathrm{x}}$ and $\mathrm{Cl}$ budgets, both 10139
ACPD

$14,10135-10166,2014$

Influence of $\mathrm{NO}_{\mathrm{x}}$ on

the activation of BrO

and $\mathrm{ClO}$ in salt

aerosol

S. Bleicher et al.

Title Page

Abstract

Introduction

Conclusions

References

Tables

Figures

14

-1

4

Back

$>$

Close

Full Screen / Esc

Printer-friendly Version

Interactive Discussion 
of which affect the troposphere's oxidizing capacity. Recently, a few hundred ppt of $\mathrm{CINO}_{2}$ have been measured in the middle of North America (Boulder, Colorado) by Thornton et al. (2010) and over continental Europe (Phillips et al., 2012). A further important class of heterogeneous reactions provides chloride to the aqueous phase 5 example such as the well-known conversion of molecular chlorine to bromine on halide surfaces: One example is the well-known conversion of molecular chlorine to bromine on halide surfaces:

$\mathrm{Cl}_{2}+\mathrm{Br}^{-}(\mathrm{aq}) \rightarrow \mathrm{BrCl}(\mathrm{aq})+\mathrm{Cl}^{-}(\mathrm{aq})$

$\mathrm{BrCl}(\mathrm{aq})+\mathrm{Br}^{-}(\mathrm{aq}) \rightleftharpoons \mathrm{Br}_{2} \mathrm{Cl}^{-}(\mathrm{aq})$

$10 \mathrm{Br}_{2} \mathrm{Cl}^{-}(\mathrm{aq}) \rightarrow \mathrm{Br}_{2}+\mathrm{Cl}^{-}(\mathrm{aq})$

and the formation of $\mathrm{HONO}$ from an uptake of $\mathrm{NOCl}$ into the aqueous phase (Scheer et al., 1997):

$\mathrm{NOCl}+\mathrm{H}_{2} \mathrm{O} \rightarrow \mathrm{HONO}+\mathrm{Cl}^{-}(\mathrm{aq})+\mathrm{H}^{+}(\mathrm{aq})$

Uptake of $\mathrm{CINO}_{2}$ is possible as well (Behnke et al., 1997), but at a slower rate compared 15 to $\mathrm{NOCl}$ (Frenzel et al.,1998). The most important source of $\mathrm{NOCl}$ is the reaction of 2 $\mathrm{NO}_{2}+\mathrm{NaCl} \rightarrow \mathrm{NOCl}+\mathrm{NaNO}_{3}$ (Finlayson-Pitts, 1983). A further minor source is the reaction of chlorine atoms with nitrogen monoxide $\left(2.19 \times 10^{-12} \mathrm{~cm}^{3}\right.$ molecule ${ }^{-1} \mathrm{~s}^{-1}$; DeMore et al., 1997).

\section{Instrumental setup and methods}

20 The experiments were performed in a $3.7 \mathrm{~m}^{3}$ Teflon chamber (FEP 200A, DuPont) with a surface to volume ratio of $3.5 \mathrm{~m}^{-1}$. In this chamber we are able to simulate the mixed aqueous and gaseous chemistry of the tropospheric mixed boundary layer (see also Bleicher, 2012). The light of seven medium pressure arc lamps $(7 \times 1200 \mathrm{~W}$, Osram HMI1200GS) below the chamber is filtered by glass (Schott, Tempax, $3 \mathrm{~mm}$ thickness)

Influence of $\mathrm{NO}_{\mathrm{x}}$ on

the activation of $\mathrm{BrO}$

and $\mathrm{ClO}$ in salt

aerosol

S. Bleicher et al.

Title Page

Abstract

Conclusions

Tables

14

4

Back
Introduction

References

Figures

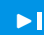

Close

Full Screen / Esc

Printer-friendly Version

Interactive Discussion 
and a water layer of $2 \mathrm{~cm}$ depth to achieve tropospheric light conditions (see Fig. 1 and appendix for photolysis frequencies). The lamps of this solar simulator have a heat-up phase after ignition lasting for three minutes and causing an increase of intensity and a shift of the spectrum. To avoid an influence on the experiment, the solar simulator was 5 shuttered for the first minutes after ignition. The shutter was removed promptly after the heat-up. The chamber was filled with zero air, containing less than 500 ppt of $\mathrm{NO}_{\mathrm{x}}$ and $\sim 500 \mathrm{ppb}$ of $\mathrm{CH}_{4}$. A slight overpressure (around $0.5 \mathrm{~Pa}$ ), measured by a differential pressure sensor (Kalinsky Elektronik DS1) and controlled by a clean air flow system, diminished the intrusion of ambient air. Since the chamber volume is dependent on the 10 overpressure, the volume specified above was measured at 0.5 Pa differential pressure by knowing the dilution flow and measuring the depletion of an inert tracer like methane in the dark (Bendix hydrocarbon analyzer, model 8201) or n-perfluorohexane.

The temperature and the relative humidity $(\mathrm{RH})$ were measured at three heights (Driesen + Kern DKRF400X-P). The salt aerosol was generated by an ultra-sonic neb15 ulizer (Quick Ohm QUV-HEV FT25/16-A, 35 W, 1.63 MHz) at RH > 50\%. The nebulized stock solution of bi-distilled water contained $1 \mathrm{gL}^{-1} \mathrm{NaCl}$ (Sigma-Aldrich, $>99 \%$, $<0.01 \% \mathrm{NaBr}$ ) and various concentrations of $\mathrm{NaBr}$ (Merck, Suprapur) ranging from 0.42 to $86.4 \mathrm{mg} \mathrm{L}^{-1}$. According to the Köhler theory (e.g. Wex et al., 2005) the concentration of salt in the stock solution determines the aerosol particle diameter to 20 about $400 \mathrm{~nm}$, with resulting ion concentrations of $6.1 \mathrm{molL}^{-1}$ of chloride and 1.5 to $300 \mathrm{mmolL}^{-1}$ of bromide. The particle size distributions were measured by a particle classifier (TSI, 3071) with a ${ }^{85} \mathrm{Kr}$ neutralizer and a condensation nucleus counter (TSI, 3020) with custom written software for scanning the size distributions and for correction for multiple charges (see also Balzer, 2012). Typical particle distributions are shown in

25 Fig. 2. Higher salt concentrations would lead to bigger particles and thus to a faster sedimentation (Siekmann, 2008). For the given particle diameter we found a lifetime (1/e-time) of ca. $5.5 \mathrm{~h}$ in our chamber by neglecting a coagulation loss for these large particle sizes. Since the particles were liquid at the given $\mathrm{RH}$, their total volume equals to the liquid water content (Iwc, given in $\mathrm{m}^{3} \mathrm{~m}^{-3}$ ). We have to note that sedimented

\section{ACPD}

$14,10135-10166,2014$

Influence of $\mathrm{NO}_{\mathrm{x}}$ on

the activation of $\mathrm{BrO}$ and $\mathrm{CIO}$ in salt aerosol

S. Bleicher et al.

Title Page

Abstract Introduction

Conclusions

Tables

References

Figures

14

$\triangleright \mathbf{I}$

4

Back

Close

Full Screen / Esc

Printer-friendly Version

Interactive Discussion 
aerosol, although not measurable, contributes to the chemistry, which results in a considerable uncertainty for the computer modeling applied in this study. A comparable chamber set-up and the wall effects on the chemistry are also discussed in a recent paper by Hoch et al. (2014).

During the experiments, the bromide concentration was varied for two reasons: (a) the influence of bromide on the activation of chloride by recombination of $\mathrm{HOBr}(\mathrm{aq})$ with chloride to $\mathrm{BrCl}$ instead of $\mathrm{Br}_{2}$ in mechanism Reaction (R7), (b) the light loss due to the Mie-scattering by the aerosol within the light path of the differential optical absorption spectrometer (DOAS). While the efficiency of mechanism (a) is a scientific 10 question (b) has a technical origin. The DOAS system has already been described in detail by Buxmann et al. (2012) and Buxmann (2012), and here we give a short overview. The instrument was equipped with a multi-reflection cell (White, 1976) with a base length of $2 \mathrm{~m}$ diagonal through the chamber using highly reflective dielectric mirrors (Layertec, $R>0.995$ between 335 and $360 \mathrm{~nm}$ ) to achieve a path length of

$288 \mathrm{~m}$. This led to a mean $\mathrm{BrO}$ and OClO detection limit of $40 \mathrm{ppt}$ and $150 \mathrm{ppt}$, respectively. The $4 \sigma$ statistical error of a single spectral fit was taken as an estimate of the detection limit. Optional broadband aluminum mirrors $(R \sim 0.90$ between $300-405 \mathrm{~nm})$ were used to observe a larger variety of species e.g. $\mathrm{ClO}, \mathrm{O}_{3}$ and $\mathrm{HONO}$ albeit at a shorter light path. For $\mathrm{ClO}$ the chosen light path of $32 \mathrm{~m}$ results in a detection limit of $\sim 800$ ppt. The integrated output light intensity after passing the White cell is proportional to the integration time of the DOAS spectra and thus influences the sensitivity. To minimize light loss, we used low aerosol concentrations (Iwc $\sim 5 \times 10^{-10}$ ) with high bromide content $\left(300 \mathrm{mmolL}^{-1}\right)$ as compensation in all experiments where DOAS was applied. Ozone was generated by an electrical discharge (Sorbios, GSG 12) in oxygen (Rießner Gase, 99.996\%) and measured by UV absorption (Thermo Scientific, 49i). $\mathrm{NO}_{2}$ was injected from gas cylinders (Rießner Gase, $101 \mathrm{ppm}$ in $\mathrm{N}_{2}$ ) and measured by chemiluminescence (Ecophysics, CLD 88p, CLD 700) with two types of converters: a photolytic converter (Ecophysics, PLC 860, mainly sensitive to $\mathrm{NO}_{2}$ ) and a molybde-

\section{ACPD}

$14,10135-10166,2014$

Influence of $\mathrm{NO}_{\mathrm{x}}$ on

the activation of $\mathrm{BrO}$

and $\mathrm{ClO}$ in salt

aerosol

S. Bleicher et al.

Title Page

Abstract

Introduction

Conclusions

Tables

References

Figures

14

-1

4

Back

Close

Full Screen / Esc

Printer-friendly Version

Interactive Discussion 
num converter (used in the CLD 700 instrument), which is sensitive to a broad spectrum of $\mathrm{NO}_{x}$ species.

The measurement of the ozone temporal variation allows us to estimate the $\mathrm{BrO}$ concentration assuming that Reaction (R10) is the dominant $\mathrm{O}_{3}$ loss process and $\mathrm{Re}$ 5 action $(\mathrm{R} 11 \mathrm{a})$ is the rate-limiting step:

$-\frac{\mathrm{d}\left[\mathrm{O}_{3}\right]}{\mathrm{d} t}=2 k_{1}[\mathrm{BrO}]^{2}+c$

where $c$ represents other ozone sinks and $k_{1}=2.7 \times 10^{-12} \mathrm{~cm}^{3}$ molecule ${ }^{-1} \mathrm{~s}^{-1}$ is the second order rate constant of Reaction (R11a). In an empty, but humidified and illuminated chamber we observe a typical ozone loss of max. $0.02 \mathrm{ppbs}^{-1}$ at ozone mixing 10 ratios below $1 \mathrm{ppm}$. This value includes a wall loss of max. $\sim 0.015 \mathrm{ppbs}^{-1}$ at typical $\mathrm{O}_{3}$-mixing ratios in the chamber and a humidity dependent loss due to the $\mathrm{O}\left({ }^{1} \mathrm{D}\right)$ photolysis channel of ozone. To estimate the BrO mixing ratio from Eq. (1), we eliminated the separately measured dilution rate (but not the wall loss) and removed the noise from the ozone curve by smoothing it using the Savitzky-Golay algorithm.

Hydrocarbons $(\mathrm{HC})$, which can be important sinks for reactive halogens, were measured by gas chromatography (Siemens Sichromat 2, Al-PLOT column $50 \mathrm{~m}$, flame ionization detector, with custom built nitrogen cold trap enrichment). By measuring the decay of a special injected HC mixture ( $n$-pentane, 2,2-dimethylbutane, 2,2,4,4tetramethylbutane, toluene) and an inert dilution standard ( $n$-perfluorohexane) we could indirectly determine the concentrations of $\mathrm{OH}$ and $\mathrm{Cl}$ radicals. This method is known as the radical clock method (RCM, Zetzsch and Behnke, 1992). It was used in selected experiments only since the $\mathrm{HC}$ species influence the halogen chemistry. The measured $\mathrm{HC}$ time profiles were interpolated by appropriate exponential and/or sigmoidal functions. The time derivatives of the fitted functions allow us to solve the set

ACPD

$14,10135-10166,2014$

Influence of $\mathrm{NO}_{\mathrm{x}}$ on

the activation of $\mathrm{BrO}$

and $\mathrm{ClO}$ in salt

aerosol

S. Bleicher et al.

Title Page

Abstract

Introduction

Conclusions

Tables

References

Figures

14

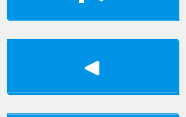

Back

Close

Full Screen / Esc

Printer-friendly Version

Interactive Discussion 
for all experimental times $t$ :

$\frac{\mathrm{d}[\mathrm{HC}]_{i}}{\mathrm{~d} t}=-k_{\mathrm{OH}, i}[\mathrm{OH}][\mathrm{HC}]_{i}-k_{\mathrm{Cl}, i}[\mathrm{Cl}][\mathrm{HC}]_{i}, \quad(i=1, \ldots, n)$

This technique was also employed to determine the solar simulator's actinic photon flux in the UV range by chlorine actinometry. UV light below $330 \mathrm{~nm}$ has a high impact 5 on the chemistry by forming excited state oxygen atoms and hence $\mathrm{OH}$ radicals by ozone photolysis. In this spectral region the chlorine actinometry is more precise than the $\mathrm{NO}_{2}$ actinometry, since the chlorine molecule has a broad absorption maximum in the UV with its maximum at $330 \mathrm{~nm}$ (e.g. Maric et al., 1993). In the irradiated chamber, the behavior of chlorine atoms basically follows the equation:

${ }_{10} \frac{\mathrm{d}[\mathrm{Cl}]}{\mathrm{d} t}=2 j\left(\mathrm{Cl}_{2}\right)\left[\mathrm{Cl}_{2}\right]-\sum_{i} k_{\mathrm{Cl}, i}[\mathrm{Cl}][\mathrm{HC}]_{i}, \quad(i=1, \ldots, n)$

where photolysis of $\mathrm{Cl}_{2}$ is the source and the I reactions with hydrocarbons are the sinks of atomic $\mathrm{Cl}$. Assuming that the photolytic decay of $\mathrm{Cl}_{2}$ is exponential and neglecting the time dependence of $\mathrm{HC}_{i}$ as a simplification (which is reasonable since the $\mathrm{HC}$ are in excess) we are able to solve Eq. (3) analytically. The solution is a bi15 exponential function of time with $j\left(\mathrm{Cl}_{2}\right)$ and $\left[\mathrm{Cl}_{2}\right]_{t=0}$ as parameters. Using the obtained $j\left(\mathrm{Cl}_{2}\right)=2.4 \times 10^{-3} \mathrm{~s}^{-1}$ we normalize the previously measured lamp spectrum by the chlorine photolysis frequency (Fig. 1). The $j\left(\mathrm{NO}_{2}\right)=6.7 \times 10^{-3} \mathrm{~s}^{-1}$ values derived from $\mathrm{Cl}_{2}$ photolysis were found to agree with $\mathrm{NO}_{2}$ actinometry $\left(j\left(\mathrm{NO}_{2}\right)=7.1 \times 10^{-3} \mathrm{~s}^{-1}\right)$ within an acceptable deviation of less than $6 \%$.

20 Additionally used in a measurement campaign was a chemical ionization mass spectrometer (CIMS), which was described by Kercher et al., 2009 to observe non-radical species. All instruments, except the GC, were connected to the chamber by Teflon tubes as short as possible with (1-3 $\mathrm{m}$ length). Chemical conversion of highly reactive bromine compounds like $\mathrm{BrO}$ or $\mathrm{HOBr}$ on instrument and inlet surfaces is a well known

Influence of $\mathrm{NO}_{x}$ on

the activation of $\mathrm{BrO}$

and $\mathrm{CIO}$ in salt

aerosol

S. Bleicher et al.

Title Page

Abstract

Introduction

Conclusions

References

Tables

Figures

14

-1

4

Back

Close

Printer-friendly Version

Interactive Discussion 
problem and can even result in a complete loss of $\mathrm{BrO}$ (Neuman et al., 2010). Therefore it is important to keep the inlet short, as it was demonstrated by Liao et al. (2011).

We compared our measurements to simulations with version 3.0 of the chemical box model CAABA/MECCA (Chemistry As A Boxmodel Application/Module Efficiently Calculating the Chemistry of the Atmosphere) by Sander et al. (2011). The model was run for $144 \mathrm{~min}$, with output every $6 \mathrm{~s}$. To represent our laboratory conditions, the "LAB" scenario in the model was set to $T=293 \mathrm{~K}, p=101325 \mathrm{~Pa}$, and a $\mathrm{RH}$ of $60 \%$. The modeled aerosol has a liquid water content of $5 \times 10^{-9} \mathrm{~m}^{3} \mathrm{~m}^{-3}$ and contains particles with a radius of $0.2 \mu \mathrm{m}$. In addition to the standard ozone, methane, $\mathrm{HO}_{\mathrm{x}}$, and $\mathrm{NO}_{\mathrm{x}}$ 10 chemistry, we activated chlorine and bromine multiphase chemistry in the gas phase and in the aerosol particles. A list of the chemical reactions used in this study, including rate coefficients and references, is available in the Supplement. Photolysis frequencies were calculated for the solar simulator by building a scalar product of the spectrum shown in Fig. 1 and the cross sections of the molecules weighted by the quantum efficiencies. All photolysis values are scaled with a single factor which represents the age of the lamps (a new lamp has ca. four times more intensity than an old lamp with more than 600 operating hours). The photolysis frequencies and the scaling factor were kept constant during the whole model simulation. For ozone, a constant destruction term of $1.3 \times 10^{-5} \mathrm{~s}^{-1}$ represents wall losses. The gas phase was initialized with $500 \mathrm{nmolmol}^{-1} \mathrm{CH}_{4}$, while the ozone and $\mathrm{NO}_{\mathrm{x}}$ mixing ratios were adapted to the conditions of individual experiments. The initial composition of the aerosol was $6.1 \mathrm{molL}^{-1}$ chloride and $0.3 \mathrm{molL}^{-1}$ bromide. The model in its original state overpredicts the concentrations of HOX species on the cost of the XO compared to the results gained from the DOAS and the CIMS experiments (see Sect. 3). We assume that the chamber walls act as a source of active halogens due to the deposits of HX from previous experiments. After testing various possibilities to include a simplified wall source $Q$, such as $\mathrm{HOX}+\mathrm{Q} \rightarrow \mathrm{X}_{2}$, we found that the addition of two reactions to the model $\mathrm{HOX} \rightarrow \mathrm{X}+\mathrm{OH}$ $\left(k=0.12 \mathrm{~s}^{-1}\right.$ for $\mathrm{X}=\mathrm{Br}$ and $0.02 \mathrm{~s}^{-1}$ for $\mathrm{X}=\mathrm{Cl}$ ) results in a good agreement with the experimental data over a wide range of initial ozone and $\mathrm{NO}_{\mathrm{x}}$ mixing ratios. Although the

10145

\section{ACPD}

$14,10135-10166,2014$

Influence of $\mathrm{NO}_{\mathrm{x}}$ on

the activation of $\mathrm{BrO}$

and $\mathrm{CIO}$ in salt

aerosol

S. Bleicher et al.

Title Page

Abstract

Introduction

Conclusions

References

Tables

Figures

14

$\Delta \mathbf{I}$

4

Back

$\rightarrow$

Close

Printer-friendly Version

Interactive Discussion 
constants are fast, this approximation is conservative since it does not add halogens to the system.

\section{Results and discussion}

From a series of experiments with various initial $\mathrm{NO}_{\mathrm{x}}$-mixing ratios we discuss four experimental runs in detail: two experiments (which are quite comparable in almost all parameters except their initial NOx mixing ratio) with the DOAS instrument and two experiments with the CIMS instrument.

\subsection{Low $\mathrm{NO}_{\mathrm{x}}$ experiment with DOAS}

The first experiment (Fig. 3 ) is a low $\mathrm{NO}_{x}$-case. Before starting the experiment, by injection of the salt aerosols, the chamber was cleaned photochemically by introducing high levels of humidity (>60\%) and ozone ( $700 \mathrm{ppb})$ and UV radiation of our solar simulator. Therefore the possibility of remaining organic from former experiments and additional wall release of $\mathrm{BrO}$ was minimized during the actual experiment. Here we nebulized a stock solution of $86.4 \mathrm{mg} \mathrm{L}^{-1} \mathrm{NaBr}$ and $1 \mathrm{gL}^{-1} \mathrm{NaCl}$ into a humid chamber $(50 \%$ rel. humidity at $293 \mathrm{~K})$, which should result in a bromide concentration of $300 \mathrm{mmolL}^{-1}$ and $6.1 \mathrm{molL}^{-1}$ chloride in the aerosol phase according to the Köhler theory. The particle concentration reached $1650 \mathrm{~cm}^{-3}$, containing $7 \times 10^{-11} \mathrm{~m}^{3} \mathrm{~m}^{-3}$ of liquid water. The particle size distribution is shown in Fig. 2a. The bromide concentration per $\mathrm{cm}^{3}$ could allow a maximal $\mathrm{Br}_{\mathrm{x}}$ mixing ratio of $515 \mathrm{ppt}$ in case of its entire activation. The nighttime chemistry (R1, R2 and R19) started by injection of ozone $(508 \mathrm{ppb})$, which induces a complete loss of the initial $\mathrm{NO}_{2}$ mixing ratio of 500 ppt. The ozone mixing ratio was nearly constant with a (dilution-corrected) loss rate of less than $-0.01 \mathrm{ppbs}^{-1}$ in the dark.

We switched the solar simulator on at $t=0$. The loss of ozone accelerated in the day 25 time conditions and reached a peak value of $-58 \mathrm{ppts}^{-1}$ after $30 \mathrm{~min}$ of illumination. As

Influence of $\mathrm{NO}_{x}$ on the activation of $\mathrm{BrO}$ and $\mathrm{ClO}$ in salt aerosol

S. Bleicher et al.

Title Page

Abstract Introduction

Conclusions

References

Tables

Figures

14

$\Delta \mathbf{I}$

4

Back

Close 
expected, the measured $\mathrm{BrO}$ concentration was correlated to the $\mathrm{O}_{3}$-derivative (slope of the ozone time profile); the peak of $[\mathrm{BrO}]=300 \pm 85$ ppt is coincident with the $\mathrm{O}_{3}$ depletion maximum. A fraction of the observed $\mathrm{BrO}$ was released by the chamber walls in a previous high ozone chamber purge without aerosol and remained as a stable 5 background level of 200 ppt of $\mathrm{BrO}$ in the chamber during the dark phase. Thus, from the BrO-mixing ratio an offset of 200 ppt was subtracted, since it was obviously an artefact remaining after the previous chamber purge. During the cleaning phase remaining organic, has been detected in form of formaldehyde by the DOAS-instrument. The formaldehyde signal was below the mean detection limit of $\sim 60 \mathrm{ppb}$, once we started 10 the salt aerosol experiment. In this experiment, the DOAS white cell was equipped with narrow band dielectric mirrors $(335-360 \mathrm{~nm}$ ) for sensitive detection of $\mathrm{BrO}$. Since the absorption cross section of $\mathrm{OCIO}$ is within the same spectral range, this species might have been the measurable indicator for an activation of chloride. However, OCIO remained below a mean detection limit of $150 \mathrm{ppt}$, and we may follow the simple relationship in Eq. (1) to calculate the contribution of bromine to the ozone loss to a value of $12 \mathrm{ppts}^{-1}$. The difference to the observed ozone loss of $55 \mathrm{ppt} \mathrm{s}^{-1} \mathrm{might}$ be caused by chlorine atoms, which were not monitored during the experiment. However, reaction constants leading to ozone loss due to chlorine (e.g. Reaction R10 and R12) and are much faster compared to bromine. It is well-known that an activation of bromide directly via mechanism Reactions (R6) and (R7) needs an acidification of the aqueous phase (e.g. Fickert et al., 1999). The $\mathrm{NO}_{2}$ mixing ratio of 500 ppt must have been sufficient to activate the entire bromide via Reactions (R16)-(R18) or to form enough $\mathrm{HNO}_{3}$ to provide the $\mathrm{H}^{+}$ions needed by Reaction (R7) via Reactions (R2) and (R3).

To decide about the dominant activation mechanism, we show a simulation run with the same starting conditions in Fig. 4. Herein plotted are the calculated mixing ratios of important trigger species vs. the total mixing ratio of gaseous $\mathrm{Br}_{\mathrm{x}}$ species. The model plausibly reproduces the experiment in terms like the ozone decay, the $\mathrm{BrO}$ mixing ratio and the loss of $\mathrm{NO}_{2}$. According to the model, a large fraction of bromide was activated directly through $\mathrm{BrNO}_{3}$ hydrolysis (mechanism Reactions R16-R18 and R7). After the

\section{ACPD}

$14,10135-10166,2014$

Influence of $\mathrm{NO}_{\mathrm{x}}$ on

the activation of $\mathrm{BrO}$ and $\mathrm{ClO}$ in salt aerosol

S. Bleicher et al.

Title Page

Abstract Introduction

Conclusions

Tables

References

Figures

14

$\triangleright \mathbf{I}$

4

Back

Close

Full Screen / Esc

Printer-friendly Version

Interactive Discussion 
$\mathrm{NO}_{2}$ was nearly consumed, the activating mechanism changed to Reactions (R14), (R15) and (R7). This is indicated by proton consumption, causing an accelerated rise of the aerosol $\mathrm{pH}$. With the model we might roughly quantify the extent of activated chlorine to a maximum of below 5 ppt $\mathrm{ClO}$ and below 3 ppt OClO. The main precursor of chlorine atoms was $\mathrm{BrCl}$, which reached 2-4 ppt here, while the mixing ratio of $\mathrm{Cl}_{2}$ (not shown), despite the lower photolysis frequency of $\mathrm{Cl}_{2}$ in comparison to $\mathrm{BrCl}$, was two orders of magnitude lower. Furthermore, $\mathrm{Br}_{2}$ reached a plateau of about $40 \mathrm{ppt}$, while the peak of gaseous $\mathrm{HOBr}$ was around $70 \mathrm{ppt}$. The major precursor of $\mathrm{HOBr}$, the $\mathrm{HO}_{2}$ radical, had an almost constant, but slightly falling mixing ratio around $50 \mathrm{ppt}$, anti10 correlated to $\mathrm{HOBr}$. The total loss of methane could be calculated to $12 \mathrm{ppb}$. The main consumer of methane was the $\mathrm{OH}$ radical with its mixing ratio of 5-10 ppt, while chlorine atoms had a minor contribution here. One important oxidation product of methane is formaldehyde, since it is a main sink for bromine atoms to form $\mathrm{HBr}$. The $\mathrm{HCHO}$ mixing ratio was calculated to be a plateau of $300 \mathrm{ppt}$. The high $\mathrm{OH}$ levels are explained

15 by the low amounts of sinks in the surrounding air. Typical $\mathrm{OH}$ values in our chamber are below $0.5 \mathrm{ppt}$ in a low $\mathrm{NO}_{\mathrm{x}}$ case and between 0.5 and $2 \mathrm{ppt}$ in a moderate $\mathrm{NO}_{\mathrm{x}}$ atmosphere, measured by RCM with injected HCs.

\subsection{High $\mathrm{NO}_{\mathrm{x}}$ experiment with DOAS}

As in the low $\mathrm{NO}_{\mathrm{x}}$ experiment, we injected aerosol into a purged and humid cham20 ber $(55 \%$ rel. humidity at $293 \mathrm{~K})$ by nebulizing a stock solution containing $1 \mathrm{~g} \mathrm{~L}^{-1} \mathrm{NaCl}$ and $86.4 \mathrm{mg} \mathrm{L}^{-1} \mathrm{NaBr}$. The aerosol reached a particle concentration of $1.8 \times 10^{4} \mathrm{~cm}^{-3}$ with a liquid water content of $5 \times 10^{-10} \mathrm{~m}^{3} \mathrm{~m}^{-3}$; its distribution is shown as curve $B$ in Fig. 2. The bromide content of $300 \mathrm{mmol} \mathrm{L}^{-1}$ would allow a maximum $\mathrm{Br}_{\mathrm{x}}$-mixing ratio of $3.65 \mathrm{ppb}$, while the chloride content would allow a maximum $\mathrm{Cl}_{\mathrm{x}}-$ mixing ratio of $78 \mathrm{ppb}$ 25 in the case of full halide activation. Figure 5 shows time profiles from this experiment, corresponding to a high- $\mathrm{NO}_{x}$ scenario. The dark chemistry started with an injection of $770 \mathrm{ppb} \mathrm{O}_{3}$, causing the exponential loss of the previously constant $\mathrm{NO}_{2}$ mixing ratio of $150 \mathrm{ppb}$. The solar simulator was switched on at minute -3 , and the shutter was still 10148

\section{ACPD}

14, 10135-10166, 2014

Influence of $\mathrm{NO}_{\mathrm{x}}$ on

the activation of $\mathrm{BrO}$

and $\mathrm{ClO}$ in salt

aerosol

S. Bleicher et al.

Title Page

Abstract

Introduction

Conclusions

Tables

References

Figures

14

DI

4

Back

$>$

Close

Full Screen / Esc

Printer-friendly Version

Interactive Discussion 
kept closed. Small light leaks around the shutter led already to a noticeable photolysis of $\mathrm{NO}_{2}$ to $\mathrm{NO}$. In daytime conditions, after opening the shutter at $t=0$, the loss of $\mathrm{NO}_{2}$ rapidly accelerated and the loss of ozone became slightly steeper. While $\mathrm{NO}_{2}$ was still present, no halogen oxides could be observed within the statistical measurement er5 ror; however we assume that mechanism Reactions (R16)-(R18) was responsible for the $\mathrm{NO}_{2}$ consumption. Once $\mathrm{NO}_{2}$ was consumed, we observed a rapid acceleration of the ozone loss, which reached two noticeable maxima after $9.5 \mathrm{~min}\left(-1.15 \mathrm{ppbs}^{-1}\right)$ and $13 \mathrm{~min}\left(-1.25 \mathrm{ppbs}^{-1}\right)$. Both maxima can be related to different periods of halogen activation. The first is most likely caused by a high involvement of bromine atoms, indi10 cated by an observed $\mathrm{BrO}$ mixing ratio of $764 \pm 44 \mathrm{ppt}$ (while the total $\mathrm{BrO}$ maximum of $841 \pm 33$ ppt was reached two minutes before). The $\mathrm{ClO}$ mixing ratio was $2770 \pm 544 \mathrm{ppt}$ at the first ozone depletion maximum with a rising tendency, reaching almost twice the value of $4114 \pm 513 \mathrm{ppt}$ at the point of the second ozone depletion maximum. The OCIO mixing ratio time series with a maximum of $6907 \pm 78 \mathrm{ppt}$ in the middle of both ozone 15 depletion maxima had a remarkable round shape. Since $\mathrm{OCIO}$ is a direct reaction product of $\mathrm{ClO}$ and $\mathrm{BrO}$ (Reaction R12), its shape can be explained by the behavior of the precursors: the decrease of $\mathrm{BrO}$ and a coincident rise of $\mathrm{ClO}$. The trapezoidal behavior of the BrO profile appears to be a consequence of stationary states involving its formation by consumption of ozone by atomic $\mathrm{Br}$ at the beginning and its consumption by 20 self-reaction and reaction with $\mathrm{ClO}$, forming $\mathrm{OClO}$. After $18 \mathrm{~min}$, the ozone was totally consumed, and the mixing ratios of the halogen oxides declined. A slight increase of the $\mathrm{NO}_{2}$ mixing ratio to a plateau of $1.5 \mathrm{ppb}$ was observed afterwards.

As well as in the low $\mathrm{NO}_{x}$ case, the model reasonably reproduces the experiment compared to most of the measured species (Fig. 6). The simulated mixing ratios of the halogen oxides species are quite comparable to the experiment, although the OCIO values are lower. This may be caused by a higher supply of bromine in the experiment, probably by the chamber walls. The consumption of ozone starts at nighttime by the production of $\mathrm{N}_{2} \mathrm{O}_{5}$, which is heterogeneously converted to $\mathrm{CINO}_{2}$ and $\mathrm{BrNO}_{2}$ on the particle surface (Reaction R19). The model calculates a total loss of bromide

\section{ACPD}

$14,10135-10166,2014$

Influence of $\mathrm{NO}_{\mathrm{x}}$ on

the activation of $\mathrm{BrO}$ and $\mathrm{CIO}$ in salt aerosol

S. Bleicher et al.

Title Page

Abstract

Introduction

Conclusions

Tables

References

Figures

14

$\triangleright \mathbf{I}$

4

Back

Close

Full Screen / Esc

Printer-friendly Version

Interactive Discussion 
following this pathway and a constant mixing ratio of $3.65 \mathrm{ppb}$ of $\mathrm{BrNO}_{2}$ after $100 \mathrm{~s}$. Also a continued loss of chloride during nighttime by forming almost $30 \mathrm{ppb}$ of $\mathrm{CINO}_{2}$ is predicted by the model. In daytime conditions both nitryl species are photolysed to $\mathrm{X}$ and $\mathrm{NO}_{2}$. The halogen atoms react with ozone and $\mathrm{NO}_{2}$ and produce $\mathrm{XNO}_{3}$ according 5 to Reaction (R16). The photodissociation of $\mathrm{XNO}_{3}$ to $\mathrm{X}$ and $\mathrm{NO}_{3}$ (Soller et al., 2002) leads to the photolytic steady state of $\mathrm{N}_{2} \mathrm{O}_{5}$ while $\mathrm{NO}_{2}$ is available in gas phase. For $\mathrm{X}=\mathrm{Br}$, Reaction (R16) replenishes the bromide in the aerosol droplets by uptake and dissociation. In a comprehensive view, the sink for most $\mathrm{NO}_{\mathrm{x}}$ and $\mathrm{XNO}_{\mathrm{x}}$ species is the formation of nitrate in the droplets.

\subsection{CIMS runs}

A CIMS measurement may give information about the direct precursors of $\mathrm{X}, \mathrm{XO}$ species, i.e. $\mathrm{X}_{2}$ and $\mathrm{XNO}_{2}$. We performed two experiments to demonstrate different mechanisms of halogen activation and conversion of active halogen species. Both experiments where done on a single day, causing some remaining reaction products and a fraction of old aerosol from the first experiment to influence the second run (see Fig. 6). In these early experiments the chamber was not cleaned before the chamber runs and thus contained $\mathrm{HC}$ and $\mathrm{NO}_{\mathrm{x}}$ (which was converted to $\mathrm{HONO}$ on the droplet surface during the aerosol injection for the first run). After the injection of ozone into the dark chamber, we observed bromine in the gas phase (both isotopes in the correct mixing ratio of $50.7 \% / 49.3 \%$ ). Since this was a nighttime formation we assume the occurrence of mechanism Reactions (R4)-(R8). Such nighttime formed gaseous bromine may trigger the auto-catalytic halide activation cycles during dawn. In daytime conditions, we observed a rapid increase of the $\mathrm{Br}_{2}$ mixing ratio, which reached its maximum of $6.1 \mathrm{ppb}$ after $7 \mathrm{~min}$ of illumination. $\mathrm{Cl}_{2}$ reached its maximum of $11.5 \mathrm{ppb} 6 \mathrm{~min}$

later. Both maxima occurred while $\mathrm{NO}_{\mathrm{x}}$ (originating from the photolysis of $\mathrm{HONO}$ ) was still present in high mixing ratios. This verifies the calculation of the halogen species concentrations $\mathrm{Cl}_{2}$ and $\mathrm{Br}_{2}$ by the model in Fig. 5. The slight increase of $\mathrm{CINO}_{2}$ after the beginning of illumination is correlated with the production of $\mathrm{N}_{2} \mathrm{O}_{5}$ from the $\mathrm{XNO}_{3}$

Influence of $\mathrm{NO}_{\mathrm{x}}$ on the activation of $\mathrm{BrO}$ and $\mathrm{ClO}$ in salt aerosol

S. Bleicher et al.

Title Page

Abstract Introduction

Conclusions

Tables

References

Figures

14

$\Delta \mathbf{I}$

4

Back

Close 
photolysis. A large fraction of $\mathrm{Cl}_{2}(8.5 \mathrm{ppb})$ remained in the gas phase after the light was switched off. It caused a heterogeneous release of bromine (Reactions R20-R22) out of fresh aerosol, which was injected in preparation of the subsequent run. Also a production of HONO was observed during the aerosol injection period. There are 5 several indicators for the occurrence of Reaction (R23): (A) the production of HONO halted with the stop of aerosol injection; Reaction (R23) provides chloride to the aerosol phase and can occur on non-saturated aerosol only. (B) The supply of chloride by Reaction (R23) during the particle generation must lead to bigger particles, which was observed after the aerosol injection for the second run. (C) The $\mathrm{NO}_{\mathrm{x}}$ measure10 ment by the CLD 700 instrument with the molybdenum $\mathrm{NO}_{\mathrm{x}}$-converter was constant (not shown), which indicates a 1:1-conversion and thus excludes the heterogeneous $2 \mathrm{NO}_{2}+\mathrm{H}_{2} \mathrm{O} \rightarrow \mathrm{HONO}+\mathrm{H}^{+}+\mathrm{NO}_{3}^{-}$reaction.

The relatively low CIMS-signals of both $\mathrm{HO}_{x}$ species and the high $\mathrm{XO}$ mixing ratios measured by DOAS led us to introduce the previously mentioned $\mathrm{HOX}$ to $\mathrm{X}+\mathrm{OH}$ 15 reactions.

\section{Summary and conclusions}

Generally speaking, the result of an experimental run is strictly dependent on the initial $\mathrm{NO}_{\mathrm{x}}$ mixing ratio. An overview of this dependence is shown in Fig. 7, where the maximum ozone decay of 42 experimental runs is plotted vs. their initial $\mathrm{NO}_{\mathrm{x}}$-levels. 20 Additionally shown are model runs with similar initial conditions. All of our experiments share a common chloride concentration in the stock solution and a common particle mean diameter. The main differences are their bromide content and the liquid water content. According to model calculations and experimental runs (full pink diamonds) the bromide content and the Iwc affect the maximum ozone decay linearly in the re25 garded range. Even at bromide levels as low as $1.5 \mathrm{mmolL}^{-1}$, where the salt was taken from commercial road salt, a strong ozone depletion is observed. Most experiments without an addition of $\mathrm{HC}$ were carried out at a IwC of $\sim 5 \times 10^{-10}$. These follow
ACPD

$14,10135-10166,2014$

Influence of $\mathrm{NO}_{\mathrm{x}}$ on

the activation of $\mathrm{BrO}$

and $\mathrm{ClO}$ in salt

aerosol

S. Bleicher et al.

Title Page

Abstract

Introduction

Conclusions

Tables

References

Figures

14

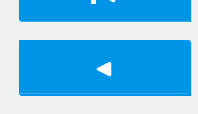

Back

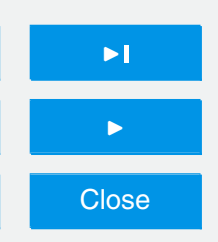

Full Screen / Esc

Printer-friendly Version

Interactive Discussion 
a logarithmic curve: $\left(\mathrm{d}\left[\mathrm{O}_{3}\right] / \mathrm{d} t\right)_{\max }=0.223 \times \ln \left(\left[\mathrm{NO}_{\mathrm{x}}\right]_{\text {init }}-0.63\right.$. The ozone loss depends strongly on of the initial nitrogen oxides mixing ratio as it is shown by the black fitting function in Fig. 7. Model runs with similar starting conditions (empty black dots) are in good agreement with the experiments at moderate and high $\mathrm{NO}_{\mathrm{x}}$ values. Even at low

$5 \mathrm{NO}_{\mathrm{x}}$ values, the model predicts faster ozone decay (red fit). We explain this difference by $\mathrm{HC}$ impurities in the lower ppb range (<10 ppb non-methane $\mathrm{HC}$, measured by FID), since $\mathrm{HCs}$ slow down the ozone depletion by scavenging the halogens to $\mathrm{HX}$ and due to an ozone production of the $\mathrm{RO}_{2}$ cycle. This can also be seen by injecting HCs (red dots). Following the model calculations one can define a noticeable release of chlorine 10 in a ppt range from $0.5 \mathrm{ppb}$ of $\mathrm{NO}_{\mathrm{x}}$, which results in an accelerated consumption of ozone. Moreover, this overview demonstrates characteristic differences between the activation in salt droplets and salt pans shown in Buxmann et al. (2012); additionally to the dependence on $\mathrm{NO}_{\mathrm{x}}$, the activation of halides from the solid phase is dependent on the liquid water layers on the crystals.

15 In all cases the activation of bromide was found to be preferred over chloride. An initial activation of bromide to $\mathrm{Br}_{2}$ may occur already in the dark, driven by dissolved ozone. The acidification of the aerosol liquid phase is often provided by nitrogen oxides. However, the influence of $\mathrm{NO}_{\mathrm{x}}$ on halogen activation is not restricted to acidification, but leads also to a heterogeneous release of photolabile reservoir species (i.e. $\mathrm{NO}_{\mathrm{x}}$, $20 \mathrm{XNO}_{2}, \mathrm{XNO}_{3}$ ) in the night and daytime; in high $\mathrm{NO}_{\mathrm{x}}$ cases bromide and chloride is activated utterly by $\mathrm{NO}_{x}$ mechanisms. Although bromide eases the release of chloride due to the equilibrium between $\mathrm{Br}_{2}+\mathrm{Cl}^{-}$and $\mathrm{BrCl}+\mathrm{Br}^{-}$, the activation of chlorine is not necessarily dependent on the bromide concentration, as measurements on road salt showed. High $\mathrm{NO}_{\mathrm{x}}$ experiments showed a strong activation of chloride even in cases where the concentration of bromide was in the lower millimolar range. Such conditions could be present on roads, which are de-iced by $\mathrm{NaCl}$-salts in winter time; they are a possible source of continental $\mathrm{CINO}_{2}$. Furthermore, the presence of chlorine and bromine would have significant impact on the tropospheric ozone level as well as methane in highly polluted coastal regions. Only a few studies exist (e.g. Osthoff

ACPD

14, 10135-10166, 2014

Influence of $\mathrm{NO}_{\mathrm{x}}$ on

the activation of $\mathrm{BrO}$

and $\mathrm{ClO}$ in salt

aerosol

S. Bleicher et al.

Title Page

Abstract

Introduction

Conclusions

Tables

References

Figures

14

DI

4

Back

$>$

Close

Full Screen / Esc

Printer-friendly Version

Interactive Discussion 
et al., 2008; Phillips et al., 2012), which do not allow a global budget. Even though, amounts of tropospheric $\mathrm{NO}_{2}$ has likely decreased by 30 to $50 \%$ in Europe and North America, it has increased by more than a factor of 2 in Asia since the mid-1990 s (Hilboll et al., 2013), which might influence the total amount of reactive bromine and 5 especially chlorine in the atmosphere, according to our findings. This should be further investigated in future studies.

Once $\mathrm{NO}_{\mathrm{x}}$ is consumed, the mechanism changes to HOX and precedes the activation cycle via the protons provided by $\mathrm{NO}_{x}$ previously. The model in its current stage reasonably reproduces chamber experiments in terms of ozone loss and halogen acti10 vation and its dependence on $\mathrm{NO}_{\mathrm{x}}$. However, the influence of the chamber walls needs to be considered as a secondary liquid phase in the model in upcoming work.

\section{Supplementary material related to this article is available online at http://www.atmos-chem-phys-discuss.net/14/10135/2014/ acpd-14-10135-2014-supplement.pdf.}

Acknowledgements. We would like to thank R. von Glasow, F. Siekmann and J. Wittmer for detailed discussions. We also thank the Deutsche Forschungsgemeinschaft for funding research unit 763.

\section{References}

Atkinson, R., Baulch, D. L., Cox, R. A., Crowley, J. N., Hampson, R. F., Hynes, R. G., Jenkin, M. E., Rossi, M. J., and Troe, J.: Evaluated kinetic and photochemical data for atmospheric chemistry: Volume III - gas phase reactions of inorganic halogens, Atmos. Chem. Phys., 7, 981-1191, doi:10.5194/acp-7-981-2007, 2007.

Balzer, N.: Kinetische Untersuchungen der Halogen-Aktivierung einer simulierten Salzpfanne in einer Smogkammer, Ph.D. thesis, University of Bayreuth, Bayreuth, Germany, 2012.

\section{ACPD}

$14,10135-10166,2014$

Influence of $\mathrm{NO}_{\mathrm{x}}$ on

the activation of $\mathrm{BrO}$

and $\mathrm{CIO}$ in salt

aerosol

S. Bleicher et al.

Title Page
Abstract

Conclusions

Tables

14

4

Back
Introduction

References

Figures

$>1$

Close
Full Screen / Esc

Printer-friendly Version

Interactive Discussion 
Behnke, W., Holländer, W., Koch, W., Nolting, F., and Zetzsch, C.: A smog chamber for studies of the photochemical degradation of chemicals in the presence of aerosols, Atmos. Environ., 22, 1113-1120, 1988.

Behnke, W., Scheer, V., and Zetzsch, C.: Formation of $\mathrm{CINO}_{2}$ and $\mathrm{HNO}_{3}$ in the presence of $5 \quad \mathrm{~N}_{2} \mathrm{O}_{5}$ and wet pure $\mathrm{NaCl}$ and wet mixed $\mathrm{NaCl} / \mathrm{Na}_{2} \mathrm{SO}_{4}$-aerosol, J. Aerosol Sci., 24, 115116, 1993.

Behnke, W., George, C., Scheer, V., and Zetzsch, C.: Production and decay of $\mathrm{CINO}_{2}$ from the reaction of gaseous $\mathrm{N}_{2} \mathrm{O}_{5}$ with $\mathrm{NaCl}$ solution: bulk and aerosol experiments, J. Geophys. Res., 102, 3795-3804, 1997.

10 Behnke, W., Elend, M., Krüger, U., and Zetzsch, C.: The influence of $\mathrm{NaBr} / \mathrm{NaCl}$ ratio on the $\mathrm{Br}^{-}$-catalysed production of halogenated radicals, J. Atmos. Chem., 34, 87-99, 1999.

Betts, R. H. and Mackenzie, A. N.: Formation and stability of hypobromous acid in perchloric acid solutions of bromine and bromate ions, Can. J. Chem., 29, 666-677, 1951.

Bleicher, S.: Zur Halogenaktivierung im deliquestzenten Aerosol und in Salzpfannen, Ph.D. thesis, University of Bayreuth, available at: http://opus4.kobv.de/opus4-ubbayreuth/files/1370/ Bleicher+Diss.pdf (last access: 1 March 2014), 2012.

Buxmann, J.: Bromine and Chlorine Explosion in a Simulated Atmosphere, Ph.D. thesis, University of Heidelberg, Heidelberg, Germany, 2012.

Buxmann, J., Balzer, N., Bleicher, S., Platt, U., and Zetzsch, C.: Observations of bromine explosions in smog chamber experiments above a model salt pan, Int. J. Chem. Kinet., 44, 312-326, 2012.

Cox, R. A. and Lewis, R.: Kinetics of chlorine oxide radical reactions using modulated photolysis, Part 3. - Pressure and temperature dependence of the reaction: $\mathrm{ClO}+\mathrm{NO}_{2}(+\mathrm{M}) \rightarrow$ $\mathrm{ClONO}_{2}(+\mathrm{M})$, J. Chem. Soc. Faraday T., 1, 75, 2649-2661, 1979.

da Rosa, M. and Zetzsch, C.: Influence of $\mathrm{pH}$ and halides on halogen species in the aqueous phase, J. Aerosol Sci., 32, S311-S312, 2001.

Deiber, G., George, Ch., Le Calvé, S., Schweitzer, F., and Mirabel, Ph.: Uptake study of $\mathrm{ClONO}_{2}$ and $\mathrm{BrONO}_{2}$ by Halide containing droplets, Atmos. Chem. Phys., 4, 1291-1299, doi:10.5194/acp-4-1291-2004, 2004.

so DeMore, W. B., Sander, S. P., Golden, D. M., Hampson, R. F., Kurylo, M. J., Howard, C. J., Ravishankara, A. R., Kolb, C. E., and Molina, M. J.: Chemical kinetics and photochemical data for use in stratospheric modeling, Evaluation number 12, JPL Publication 97-4, Jet Propulsion Laboratory California Institute of Technology Pasadena, California, 1-266, 1997.

\section{ACPD}

$14,10135-10166,2014$

Influence of $\mathrm{NO}_{\mathrm{x}}$ on

the activation of $\mathrm{BrO}$

and $\mathrm{ClO}$ in salt

aerosol

S. Bleicher et al.

Title Page

Abstract

Introduction

Conclusions

References

Tables

Figures

14

$>1$

4

Back

$>$

Close

Full Screen / Esc

Printer-friendly Version

Interactive Discussion 
Fickert, S., Adams, J. W., and Crowley, J. N.: Activation of $\mathrm{Br}_{2}$ and $\mathrm{BrCl}$ via uptake of $\mathrm{HOBr}$ onto aqueous salt solutions, J. Geophys. Res., 104, 23719-23727, 1999.

Finlayson-Pitts, B. J.: Reaction of $\mathrm{NO} 2$ with $\mathrm{NaCl}$ and atmospheric implications of $\mathrm{NOCl}$ formation, Nature, 306, 676-677, 1983.

5 Finlayson-Pitts, B. J., Ezell, M. J., Pitts Jr., J. N.: Formation of chemically active chlorine compounds by reactions of atmospheric $\mathrm{NaCl}$ particles with gaseous $\mathrm{N}_{2} \mathrm{O}_{5}$ and $\mathrm{ClONO}_{2}$, Nature, 337, 241-244, 1989.

Frenzel, A., Scheer, V., Sikorski, R., George, C., Behnke, W., and Zetzsch C.: Heterogeneous interconversion reactions of $\mathrm{BrNO}_{2}, \mathrm{ClNO}_{2}, \mathrm{Br}_{2}$, and $\mathrm{Cl}_{2}$, J. Phys. Chem. A, 102, 1329-1337, 1998.

George, C., Ponche, J. L., Mirabel, P., Behnke, W., Scheer, V., and Zetzsch, C.: Study of the uptake of $\mathrm{N}_{2} \mathrm{O}_{5}$ by water and $\mathrm{NaCl}$ solutions, J. Phys. Chem., 98, 8780-8784, 1994.

Hanson, D. R., Ravishankara, D. R., and Lovejoy, E. R.: Reaction of $\mathrm{BrONO}_{2}$ with $\mathrm{H}_{2} \mathrm{O}$ on submicron sulfuric acid aerosol and the implications for the lower stratosphere, J. Geophys.

15 Res., 101, 9063-9069, 1996.

Hippler, H., Krasteva, N., Nasterlack, S., and Striebel, F.: Reaction of $\mathrm{OH}+\mathrm{NO}_{2}$ : high pressure experiments and falloff analysis, J. Phys. Chem. A, 110, 6781-6788, 2006.

Hilboll, A., Richter, A., and Burrows, J. P.: Long-term changes of tropospheric $\mathrm{NO}_{2}$ over megacities derived from multiple satellite instruments, Atmos. Chem. Phys., 13, 4145-4169, doi:10.5194/acp-13-4145-2013, 2013.

Hoch, D. J., Buxmann, J., Sihler, H., Pöhler, D., Zetzsch, C., and Platt, U.: An instrument for measurements of BrO with LED-based Cavity-Enhanced Differential Optical Absorption Spectroscopy, Atmos. Meas. Tech., 7, 199-214, doi:10.5194/amt-7-199-2014, 2014.

Hunt, S. W., Roeselová, M., Wang, W., Wingen, L. M., Knipping, E. M., Tobias, D. J., Dabdub, D., and Finlayson-Pitts, B. J.: Formation of molecular bromine from the reaction of ozone with deliquesced $\mathrm{NaBr}$ aerosol: evidence for interface chemistry, J. Phys. Chem. A, 108, 1155911572, 2004.

Kercher, J. P., Riedel, T. P., and Thornton, J. A.: Chlorine activation by $\mathrm{N}_{2} \mathrm{O}_{5}$ : simultaneous, in situ detection of $\mathrm{CINO}_{2}$ and $\mathrm{N}_{2} \mathrm{O}_{5}$ by chemical ionization mass spectrometry, Atmos. Meas.

$30 \quad$ Tech., 2, 193-204, doi:10.5194/amt-2-193-2009, 2009.

Liao, J., Sihler, H., Huey, L. G., Neuman, J. A., Tanner, D. J., Friess, U., Platt, U., Flocke, F. M., Orlando, J. J., Shepson, P. B., Beine, H. J., Weinheimer, A. J., Sjostedt, S. J., Nowak, J. B., Knapp, D. J., Staebler, R. M., Zheng, W., Sander, R., Hall, S. R., and Ullmann, K.:

Influence of $\mathrm{NO}_{\mathrm{x}}$ on

the activation of $\mathrm{BrO}$

and $\mathrm{ClO}$ in salt

aerosol

S. Bleicher et al.

Title Page

Abstract

Introduction

Conclusions

References

Tables

Figures

14

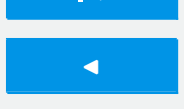

$>$ I

Back

$>$

Close

Full Screen / Esc

Printer-friendly Version

Interactive Discussion 
A comparison of Arctic $\mathrm{BrO}$ measurments by chemical ionization mass spectrometry and long path-differential optical absorbtion spectroscopy, J. Geophys. Res., 116, D00R02, doi:10.1029/2010JD014788, 2011.

Lopez-Hilfiker, F. D., Constantin, K., Kercher, J. P., and Thornton, J. A.: Temperature dependent 5 halogen activation by $\mathrm{N}_{2} \mathrm{O}_{5}$ reactions on halide-doped ice surfaces, Atmos. Chem. Phys., 12, 5237-5247, doi:10.5194/acp-12-5237-2012, 2012.

Madronich, S. and Flocke, S.: The role of solar radiation in atmospheric chemistry, in: The Handbook of Enviromental Chemistry, vol. 2, Part I: Environmental Photochemistry, edited by: Boule, P., Springer, Berlin, 1-26, 1999.

10 Maric, D., Burrows, J. P., Meller, R., and Moortgat, G. K.: Visible absorption spectra of molecular chlorine, J. Photochem. Photobiol. A, 70, 205-214, 1993.

Morris, J. C.: The acid ionization constant of $\mathrm{HOCl}$ from 5 to $35^{\circ}$, J. Phys. Chem., 70, 37983805, 1966.

Palm, W.-U., Elend, M., Krüger, H.-U., and Zetzsch, C.: OH radical reactivity of airborne ter-

15 buthylazine adsorbed on inert aerosol, Environ. Sci. Technol., 31, 3389-3396, 1997.

Neuman, J. A., Nowak, J. B., Huey, L. G., Burkholder, J. B., Dibb, J. E., Holloway, J. S., Liao, J., Peischl, J., Roberts, J. M., Ryerson, T. B., Scheuer, E., Stark, H., Stickel, R. E., Tanner, D. J., and Weinheimer, A.: Bromine measurements in ozone depleted air over the Arctic Ocean, Atmos. Chem. Phys., 10, 6503-6514, doi:10.5194/acp-10-6503-2010, 2010.

Osthoff, H. D., Roberts, J. M., Ravishankara, A. R., Williams, E. J., Lerner, B. M., Sommariva, R., Bates, T. S., Derek Coffman, D., Quinn, P. K., Dibb, J. E., Stark, H., Burkholder, J. B., Talukdar, R. K., Meagher, J., Fehsenfeld, F. C., and Brown, S. S.: High levels of nitryl chloride in the polluted subtropical marine boundary layer, Nat. Geosci., 1, 324-328, 2008.

Peters, C., Pechtl, S., Stutz, J., Hebestreit, K., Hönninger, G., Heumann, K. G., Schwarz, A., Winterlik, J., and Platt, U.: Reactive and organic halogen species in three different European coastal environments, Atmos. Chem. Phys., 5, 3357-3375, doi:10.5194/acp-5-3357-2005, 2005.

Phillips, G. J., Tang, M. J., Thieser, J., Brickwedde, B., Schuster, G., Bohn, B., Lelieveld, J., and Crowley, J. N.: Significant concentrations of nitryl chloride observed in rural continental Europe associated with the influence of sea salt chloride and anthropogenic emissions, Geophys. Res. Lett., 39, L10811, doi:10.1029/2012GL051912, 2012.

Influence of $\mathrm{NO}_{\mathrm{x}}$ on

the activation of $\mathrm{BrO}$

and $\mathrm{CIO}$ in salt

aerosol

S. Bleicher et al.

Title Page

Abstract

Introduction

Conclusions

References

Tables

Figures

14

-1

4

Back

$>$

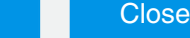

Full Screen / Esc

Printer-friendly Version

Interactive Discussion 
Platt, U. and Janssen, C.: Observation and role of the free radicals $\mathrm{NO}_{3}, \mathrm{ClO}, \mathrm{BrO}$ and $\mathrm{IO}$ in the troposphere, Faraday Discuss., 100, 175-198, 1995.

Pratt, K. A., Custard, K. D., Shepson, P. B., Douglas, T. A., Pöhler, D., General, S., Zielcke, J., Simpson, W. R., Platt, U., Tanner, D. J., Huey, G. L., Carlsen, M., and Stirm, B. H.: Photochemical production of molecular bromine in Arctic surface snowpacks, Nat. Geosci., 6 , 351-356, 2013.

Rossi, M. J.: Heterogeneous reactions on salts, Chem. Rev., 103, 4823-4882, 2003.

Sander, R., Baumgaertner, A., Gromov, S., Harder, H., Jöckel, P., Kerkweg, A., Kubistin, D., Regelin, E., Riede, H., Sandu, A., Taraborrelli, D., Tost, H., and Xie, Z.-Q.: The atmospheric chemistry box model CAABA/MECCA-3.0, Geosci. Model Dev., 4, 373-380, doi:10.5194/gmd-4-373-2011, 2011.

Sander, S. P., Ray, G. W., and Watson, R. T.: Kinetics study of the pressure dependence of the $\mathrm{BrO}+\mathrm{NO}_{2}$ reaction at 298 Kelvin, J. Phys. Chem., 85, 199-210, 1981.

Scheer, V., Frenzel, A., Behnke, W., Zetzsch, C., Magi, L., George, C., and Mirabel, P.: Uptake of nitrosyl chloride (NOCl) by aqueous solutions, J. Phys. Chem. A, 101, 9359-9366, 1997.

Schütze, M. and Herrmann, H.: Determination of phase transfer parameters for the uptake of $\mathrm{HNO}_{3}, \mathrm{~N}_{2} \mathrm{O}_{5}$ and $\mathrm{O}_{3}$ on single aqueous drops, Phys. Chem. Chem. Phys., 4, 60-67, 2002.

Shilov, E. A.: On the calculation of the dissociation constants of hypohalogenous acids from kinetic data, J. Am. Chem. Soc., 60, 490-491, 1938.

20 Soller, R., Nicovich, J. M., and Wine, P. H.: Bromine nitrate photochemistry: quantum yields for $\mathrm{O}, \mathrm{Br}$, and $\mathrm{BrO}$ over the wavelength range $248-355 \mathrm{~nm}$, J. Phys. Chem., 106, 8378-8385, 2002.

Thornton, J. A., Kercher, J. P., Riedel, T. P., Wagner, N. L., Cozic, J., Holloway, J. S., Dube, W. P., Wolfe, G. M., Quinn, P. K., Middlebrook, A. M., Alexander, B., and Brown, S. S.: A large atomic chlorine source inferred from midcontinental reactive nitrogen chemistry, Nature, 464, 271274, 2010.

Wex, H., Kiselev, A., Stratmann, F., Zoboki, J., and Brechtel, F.: Measured and modeled equilibrium sizes of $\mathrm{NaCl}$ and $\left(\mathrm{NH}_{4}\right)_{2} \mathrm{SO}_{4}$ particles at relative humidities up to $99.1 \%$, J. Geophys. Res., 110, D21212, doi:10.1029/2004JD005507, 2005.

30 Wren, S. N., Donaldson, D. J., and Abbatt, J. P. D.: Photochemical chlorine and bromine activation from artificial saline snow, Atmos. Chem. Phys., 13, 9789-9800, doi:10.5194/acp-139789-2013, 2013.

\section{ACPD}

14, 10135-10166, 2014

Influence of $\mathrm{NO}_{\mathrm{x}}$ on

the activation of BrO

and $\mathrm{ClO}$ in salt

aerosol

S. Bleicher et al.

Title Page

Abstract

Introduction

Conclusions

Tables

References

\section{Figures}

14

4

Back

Close

Full Screen / Esc

Printer-friendly Version

Interactive Discussion 
Zetzsch, C. and Behnke, W.: Heterogeneous photochemical sources of atomic $\mathrm{Cl}$ in the troposphere, Ber. Bunsen. Phys. Chem., 96, 488-493, 1992.

\section{ACPD}

14, 10135-10166, 2014

Influence of $\mathrm{NO}_{\mathrm{x}}$ on the activation of $\mathrm{BrO}$ and $\mathrm{ClO}$ in salt aerosol

S. Bleicher et al.

Title Page

Abstract

Conclusions

Tables

14

4

Back

Introduction

References

Figures

$>$ I

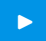

Close

Full Screen / Esc

Printer-friendly Version

Interactive Discussion 


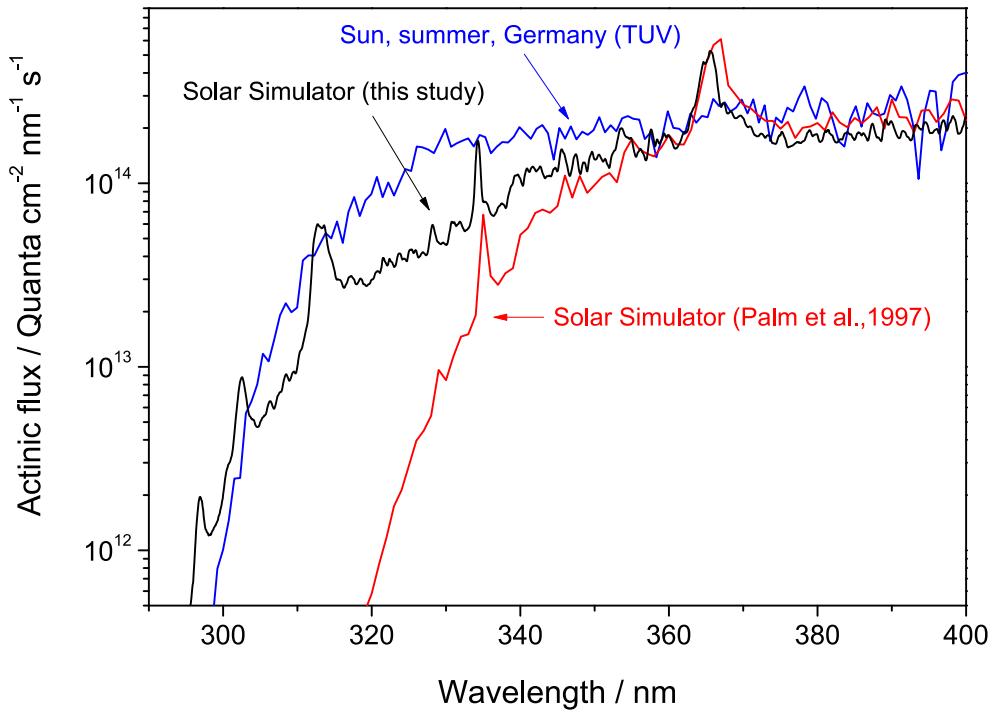

Fig. 1. Measured actinic photon flux in comparison to the sun in mid summer in Germany, calculated by Tropospheric Ultraviolet \& Visible Radiation Model (TUV, Madronich and Flocke, 1999) and to a previous publication (Palm et al., 1997) with a glass filter that had been in use for 15 years. The glass filter is subject to solarization, which moves the UV-cutoff to red.
ACPD

14, 10135-10166, 2014

Influence of $\mathrm{NO}_{\mathrm{x}}$ on the activation of $\mathrm{BrO}$ and $\mathrm{ClO}$ in salt aerosol

S. Bleicher et al.

Title Page
Abstract

Conclusions

Tables

14

Back

\section{Introduction}

References

Figures

$\Delta$

Close

\section{Full Screen / Esc}

Printer-friendly Version

Interactive Discussion 


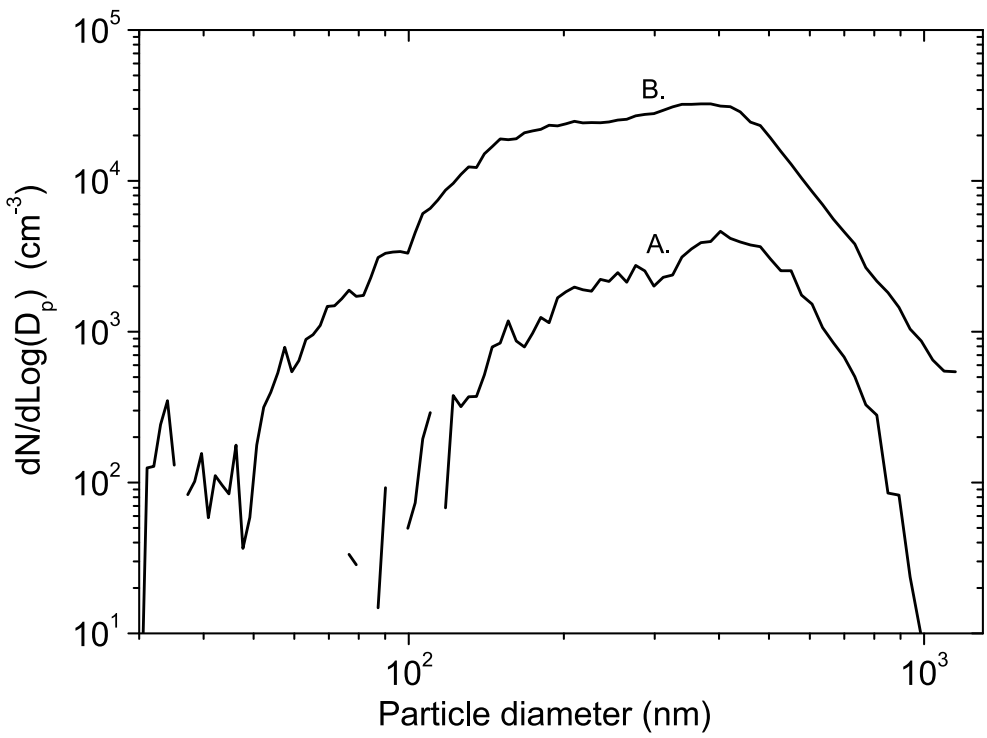

Fig. 2. Initial particle size distributions of the experiments discussed below. Both aerosols were generated from the same stock solution of $1 \mathrm{gL}^{-1} \mathrm{NaCl}$ and $86.4 \mathrm{mg} \mathrm{L}^{-1} \mathrm{NaBr}$, resulting in a common maximum at nearly at $400 \mathrm{~nm}$. Run A was one of the first aerosol experiments with the DOAS instrument, where the particle concentration was kept lower to test the light loss by the Mie scattering. The content of liquid water was thus lower in run $A\left(7 \times 10^{-11}\right)$ compared to run $B\left(5 \times 10^{-10}\right)$.
Influence of $\mathrm{NO}_{\mathrm{x}}$ on the activation of $\mathrm{BrO}$ and $\mathrm{ClO}$ in salt aerosol

S. Bleicher et al.

\section{Title Page}

\section{Abstract}

Conclusions

Tables

14

Back

\section{Full Screen / Esc}

Printer-friendly Version 


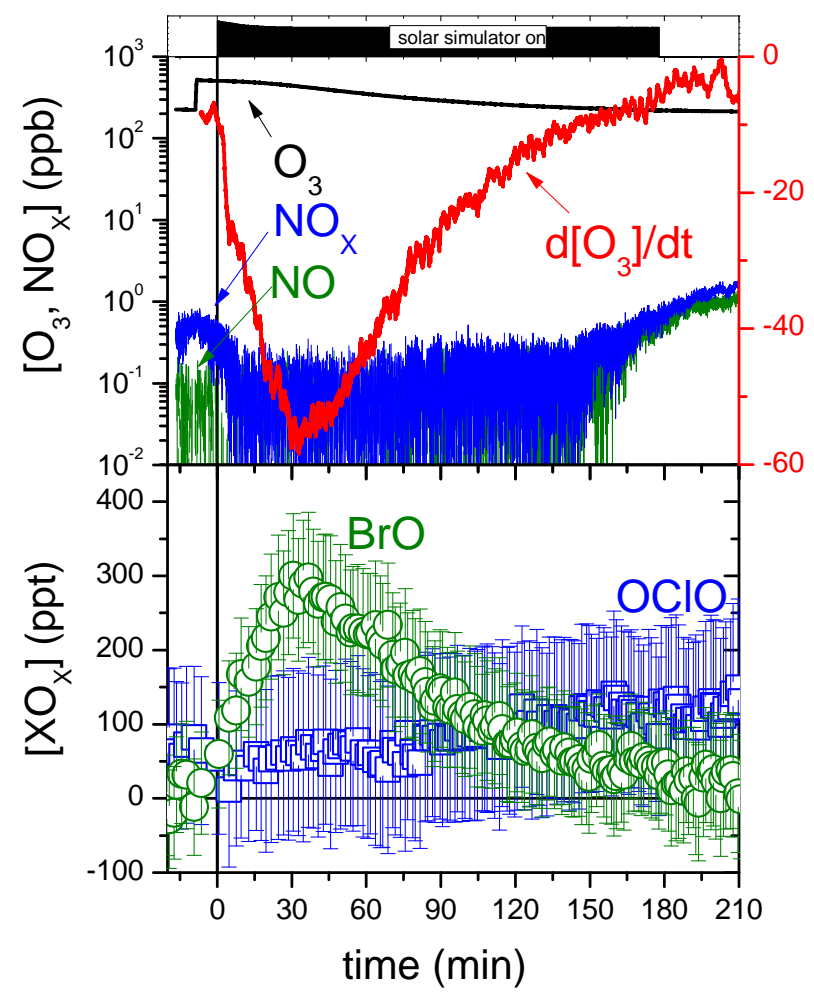

Fig. 3. Activation of bromide and its impact on ozone in a low $\mathrm{NO}_{x}$ scenario. A part of the $\mathrm{BrO}$ mixing ratio (200 ppt) was subtracted as an artifact from the previous chamber purge, since it was stable under night time conditions.

\section{ACPD}

14, 10135-10166, 2014

Influence of $\mathrm{NO}_{\mathrm{x}}$ on the activation of $\mathrm{BrO}$ and $\mathrm{ClO}$ in salt aerosol

\section{S. Bleicher et al.}

\section{Title Page}

Abstract

Conclusions

Tables

14

Back

\section{Full Screen / Esc}

Printer-friendly Version

Interactive Discussion 

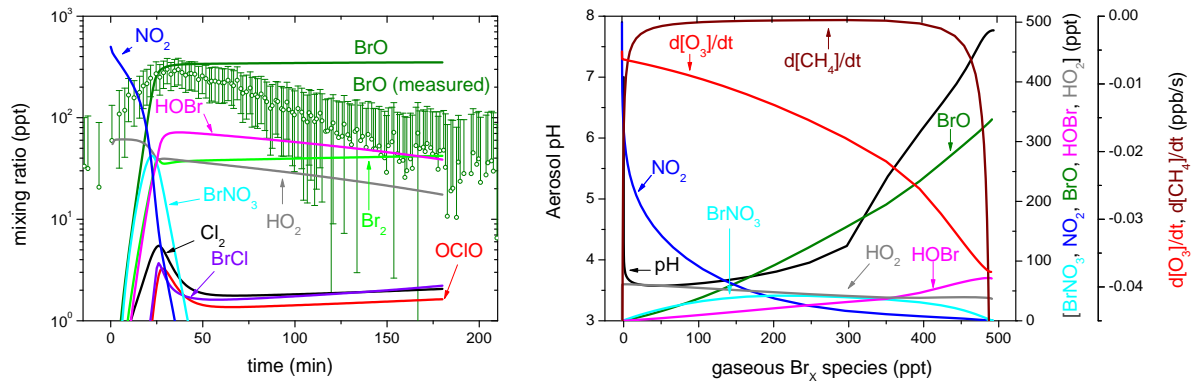

Influence of $\mathrm{NO}_{\mathrm{x}}$ on

the activation of $\mathrm{BrO}$

and $\mathrm{ClO}$ in salt

aerosol

S. Bleicher et al.

Title Page

\section{Abstract}

Conclusions

Tables gaseous $\mathrm{Br}_{\mathrm{x}}$ species coming from the loss of bromide of the liquid phase. The modeled $\mathrm{BrO}$ reaches a stationary state at $350 \mathrm{ppt}$ after $35 \mathrm{~min}$ with a slower decrease than the experiment and confirms a low level of $\mathrm{OClO}$ of $3 \mathrm{ppt}$, well below the detection limit of the DOAS instrument. The change of the activation regime during "day time" from $\mathrm{BrNO}_{3}$ to $\mathrm{HOBr}$ after the $\mathrm{NO}_{2}$ has almost completely been consumed and is indicated by a fast consumption of protons as it can be seen in the right figure.

Fig. 4. Model calculation of the experiment shown in Fig. 3. Time profiles are plotted in the left figure, while in the right figure the data of the first $30 \mathrm{~min}$ is plotted against the gained

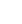




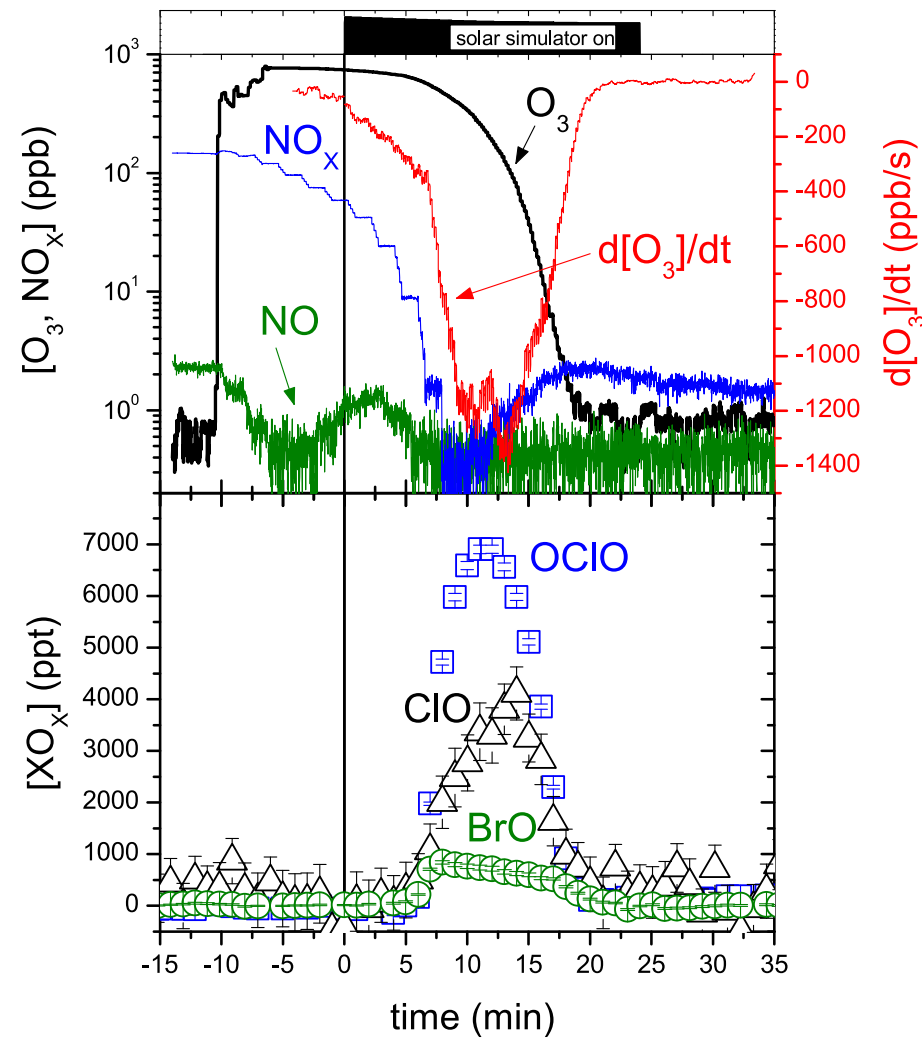

ACPD

14, 10135-10166, 2014

Influence of $\mathrm{NO}_{\mathrm{x}}$ on the activation of $\mathrm{BrO}$ and $\mathrm{ClO}$ in salt aerosol

S. Bleicher et al.

Title Page

Abstract

Conclusions

Tables

14

4

Back

\section{Full Screen / Esc}

Printer-friendly Version

Interactive Discussion 


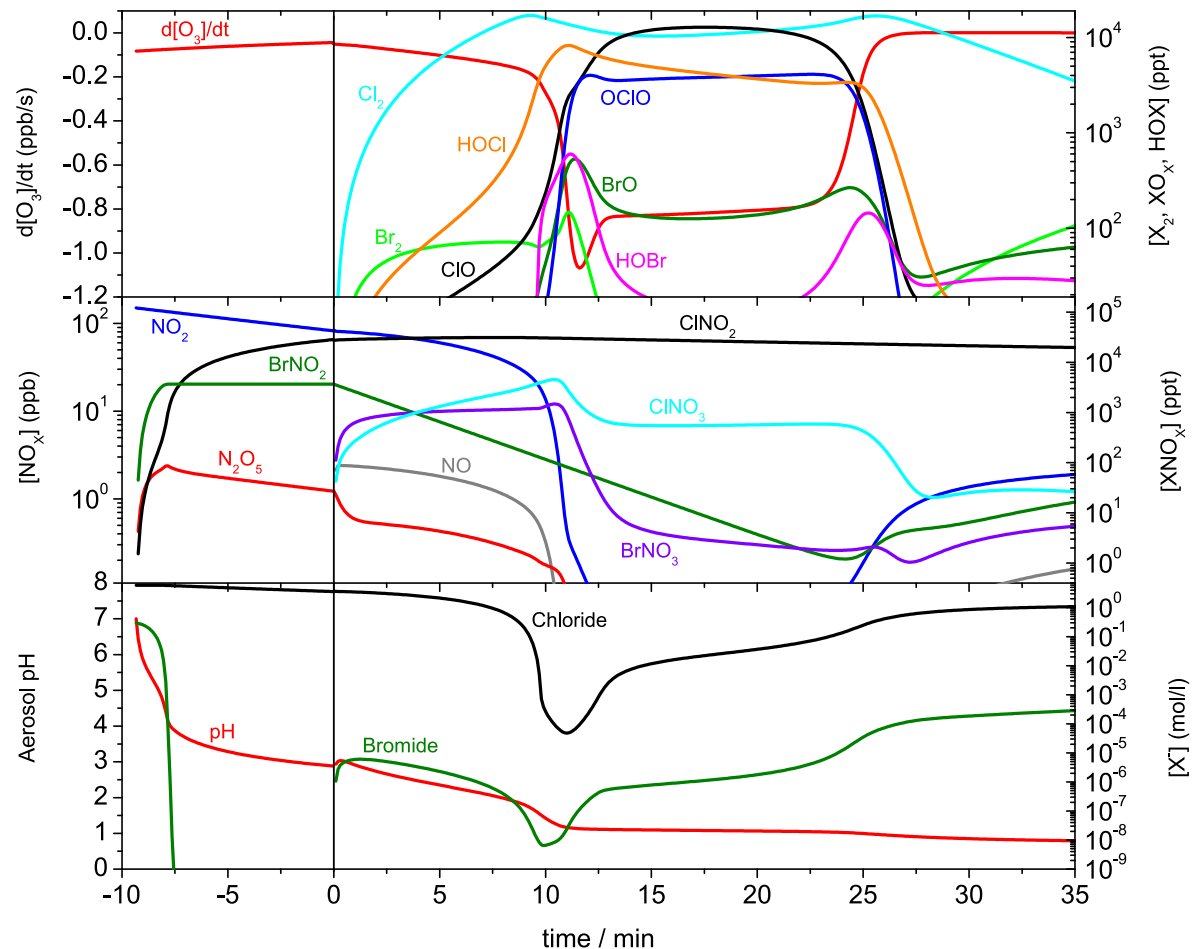

Fig. 6. Model calculation of halogen activation in a high $\mathrm{NO}_{\mathrm{x}}$ scenario. Although the values of ozone depletion are comparable to the experiment, the simulation is $3-5 \mathrm{~min}$ delayed. This can be explained with wall sources from previous experiments. A higher simulated content of bromide in the liquid phase would explain a faster consumption of ozone and higher OCIO mixing ratios as observed. In the logarithmic scale is the photolysis of $\mathrm{CINO}_{2}$ almost imperceptible: the $\mathrm{CINO}_{2}$ mixing ratio raises right after the day time conditions are switched on while $\mathrm{NO}_{x}$ is still available and declines after with its photolytic life time of $3 \times 10^{-4} \mathrm{~s}^{-1}$.
ACPD

$14,10135-10166,2014$

Influence of $\mathrm{NO}_{\mathrm{x}}$ on the activation of $\mathrm{BrO}$

and $\mathrm{CIO}$ in salt aerosol

S. Bleicher et al.

Title Page

\section{Abstract}

Conclusions

Tables

14

Back

\section{Introduction}

References

Figures

$>1$

Close
Full Screen / Esc

Printer-friendly Version

Interactive Discussion 


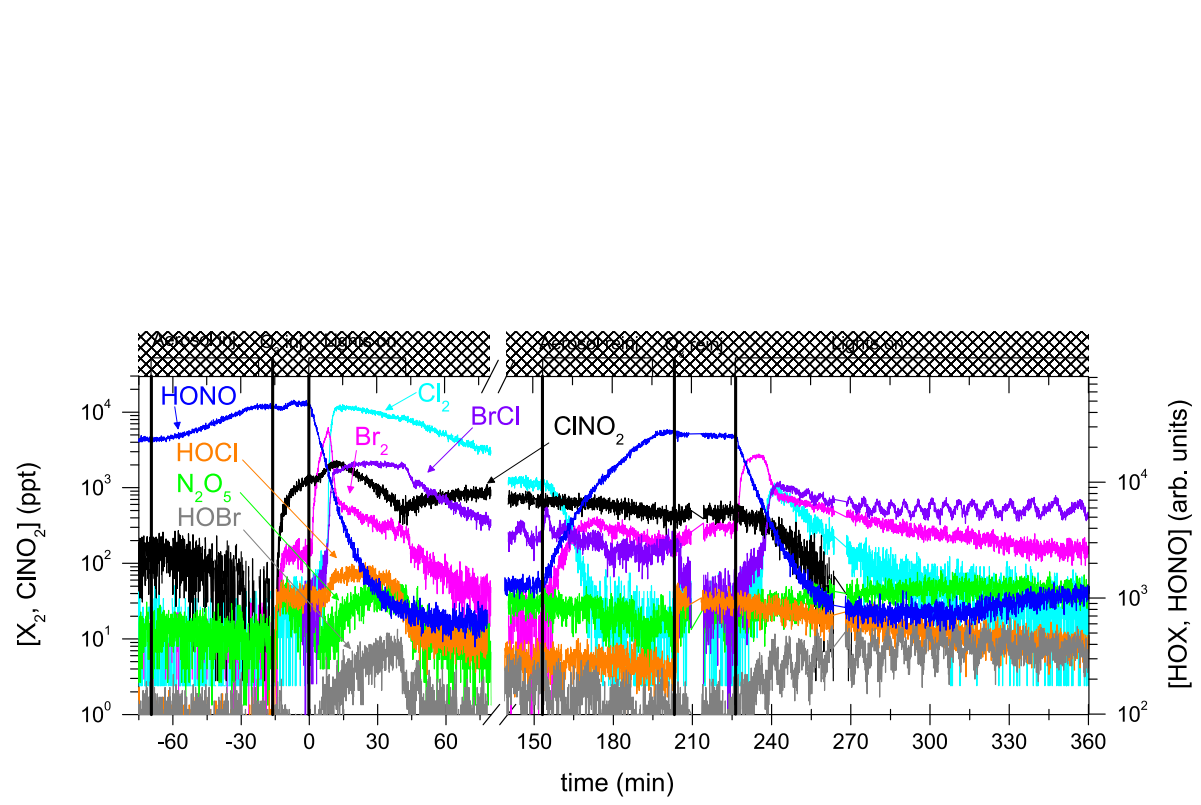

\section{ACPD}

14, 10135-10166, 2014

Influence of $\mathrm{NO}_{\mathrm{x}}$ on the activation of $\mathrm{BrO}$

and $\mathrm{CIO}$ in salt aerosol

S. Bleicher et al.

\section{Title Page}

Conclusions

Fig. 7. $\mathrm{CIMS}$ measurement of $\mathrm{HONO}$ and the direct precursors of $\mathrm{BrO}\left(\mathrm{Br}_{2}\right.$ and $\left.\mathrm{HOBr}\right)$ and $\mathrm{CIO}\left(\mathrm{Cl}_{2}, \mathrm{CINO}_{2}\right.$ and $\left.\mathrm{HOCl}\right)$. The chamber contained a sum of $25 \mathrm{ppb}$ of $\mathrm{HONO}$ and $\mathrm{NO}_{\mathrm{x}}$ from ambient air impurities. During the aerosol injection, $\mathrm{NO}_{\mathrm{x}}$ was heterogeneously converted to HONO. Its decay during daytime conditions suits the measured photolysis frequency of $j(\mathrm{HONO})=2 \times 10^{-3} \mathrm{~s}^{-1}$. The maximum values of $\mathrm{Br}_{2}$ and $\mathrm{Cl}_{2}$ were reached while $\mathrm{NO}_{\mathrm{x}}$ as a product of HONO.

\section{Abstract}

Tables

14

4

Back

Introduction

References

Figures

DI

Close

\section{Full Screen / Esc}

Printer-friendly Version

Interactive Discussion 


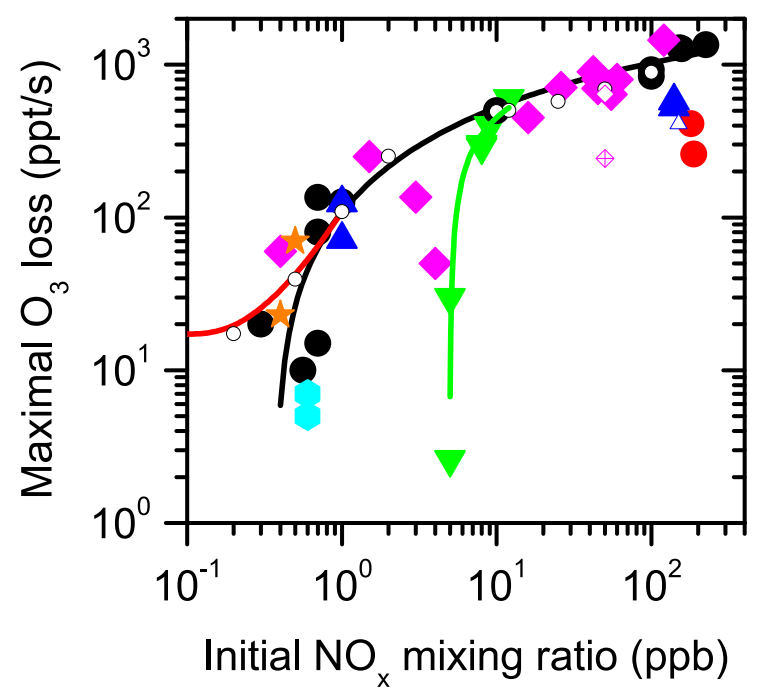

Fig. 8. Dependence of the maximum ozone loss on the initial $\mathrm{NO}_{\mathrm{x}}$ concentration for $1 \mathrm{gL}^{-1} \mathrm{NaCl}$ aerosol with different bromide contents and variations of other parameters. The full symbols are experiments: black circles $-0.3 \mathrm{molL}^{-1}$ bromide and Iwc $5 \times 10^{-10}$, red circles $-0.3 \mathrm{molL}^{-1}$ bromide and Iwc $5 \times 10^{-10}$ and additional VOC injected, blue triangles $-1.5 \mathrm{mmolL}^{-1}$ (road salt) bromide and Iwc $5 \times 10^{-10}$, green triangles - salt pan experiments from Buxmann et al., 2012, pink diamonds $-0.03 \mathrm{~mol} \mathrm{~L}^{-1}$ bromide and Iwc $5 \times 10^{-9}$, cyan dots $-5.2 \mathrm{mmolL}^{-1}$ bromide and Iwc $5 \times 10^{-9}$, orange asterisks $-52 \mathrm{mmolL}^{-1}$ bromide and Iwc $5 \times 10^{-9}$. The open symbols are model runs with initial parameters corresponding to the experiments. The black curve was fitted to the full black circles, while the red curve was fitted to the open black circles. In the low range the model differs from the experiment due to VOC impurities in the zero air which slow down the halogen chemistry. The salt pan experiments are slowed down due to low rel. humidity.

\section{ACPD}

14, 10135-10166, 2014

Influence of $\mathrm{NO}_{x}$ on the activation of $\mathrm{BrO}$ and $\mathrm{CIO}$ in salt aerosol

S. Bleicher et al.

Title Page
Abstract

Conclusions

Tables

14

4

Back
Introduction

References

Figures

$>1$

Close
Full Screen / Esc

Printer-friendly Version

Interactive Discussion 